\title{
Designing A Standard Operating Procedure (SOP) For Restructuring A Language Centre In A Buddhist College
}

\author{
Maria Fransisca Andanti \\ Magister Manajemen Pendidikan Universitas Kristen Satya Wacana \\ 942017015@student.uksw.edu \\ Bambang Suteng Sulasmono \\ Magister Manajemen Pendidikan Universitas Kristen Satya Wacana \\ sulasmonobambang@yahoo.com \\ Mawardi \\ Magister Manajemen Pendidikan Universitas Kristen Satya Wacana \\ mawardi@uksw.edu
}

\begin{abstract}
The purpose of the research is designing a Standard Operating Procedure (SOP) in a language centre of a Buddhist college. The SOP was designed as part of the restructuring process of the language centre, aimed at regaining the language centre's function as a language centre, not language teaching centre as it had been happening. By employing three phases of Branch's ADDIE (2009), Analyze, Design, and Develop, the study produced an SOP of the language centre's program that was aimed at guiding the management team to design and implement the programs in language centre based on the three areas of language centre's activity. The data was gathered through interview, document study, and observation. It then was analyzed through data condensation, data display, and drawing and verification conclusions (Miles, Huberman, \& Saldaña, 2014). The SOP focused on three kinds of programs to accommodate the diverse and complex activities the LC should have tackled as a language centre.
\end{abstract}

Keywords: Standard Operating Procedure (SOP), Language Centre, ADDIE Approach

\section{Article Info}

\section{INTRODUCTION}

Organization is a set of people that intentionally works together to achieve a set of similar purposes or specific purpose (Kinicki \& Williams, 2013; Tran \& Tian, 2013; and Ferdous, 2016). To be able to achive its defined purposes, any organization needs a good management system. Cuban (1988), as cited by Bush (2007: 392) mentioned that the basic principle of managing is "maintaining efficiently and effectively current organizational arrangements". In fact, managers often take some actions to ensure that their organizations run effectively and efficiently. One of the actions is by applying Standard Operating Procedure (SOP) to guide staff for performing specific operation. 
SOP has been widely used as an instrument to guide people in organization to implement procedures step by step. It is a set of instructions used to accomplish a set of tasks as a standard procedure in an organization (Bhattacharya, 2015; Barbé, et. al, 2016; Sadjak, Trembath, \& Thomas, 2013; Putranti, 2016). As it is a process document that describes in detail the way that an operator should perform a given operation (de Treville, Antonakis, \& Edelson, 2005), it does not only cover a set of instructions, but also any detail informing who are involved, their responsibilities, and their positions. Akyar (2012) highlighted the importance of SOP in an organization since it enables people in organization to complete their given tasks in the same way so that it allows control towards the organization's quality.

There have been many forms of SOP, but basically, there are four things needed to be considered; they are objective, scope, responsibility, and procedure (Battacharya, 2016). Objective aims to lay down procedure for the preparation of Standard Operating Procedure (Battacharya, 2016). Scope should ensure that the procedure is applicable to all the SOPs throughout the organization (Battacharya, 2016). Responsibility describes the person performing or the respective Head of Department of concerning departments and person monitoring or the Quality Assurance officer or Head of Department Quality Assurance (Battacharya, 2016). And, to write down the procedure, it is important to understand that all SOPs should be computer typed using Times New Roman font (Battacharya, 2016). The format should be per Annexure SOP/QA/002/1 (Battacharya, 2016). SOP should also have Header, Signature Block, and Body (Battacharya, 2016).

SOP is applied because sometimes "things do not go smoothly" in organization. In fact, many organizations have management problems so that they are not able to develop and function properly. A language centre in a Buddhist college is one of them. It has been operating for five years and focused more on language teaching and training. Besides, it only plays role in the language program of Undergraduate Study Program by conducting English Certified Program. The language centre (LC) did not hold any language program in the Graduate Program and once conducted an English matriculation program. This condition leads to the LC's shifting role as a language teaching centre, not language centre.

Moreover, the LC is the first language institution established by the founding institution. It means that it is the first ever experience to manage a language centre. Since it was established in 2014, the LC also did not have any SOP applied in their managerial activities.

In reality, there has been some misconception of the function of language centres at universities (Meyer, 1997 as cited Ruane, 2003). Senior managerial team at university tends to consider that the role of language centre is only providing language training and ignore the bigger role it may contribute for the development of the founding institution itself. Nevertheless, there is a clear different between language centre and language teaching centre (Ingram, 2001). According to Ingram (2001), there are three main areas of language centre. They are applied linguistics (language research, consultancy, and teaching and training), the improvement of language education, and the implementation of language policy in the institution, nation or region that they serve. It is also important to note that language centre and language teaching centre are two different things, since language centre may or not include language teaching in their activities.

However, research should become the central activity in language centre. A language centre must contribute to the development of language education through their extensive 
research practices. The research practices might become an alignment to university (Ruane, 2003) that will change its work status among the departments in university. Therefore, language centre needs to take a more structured approach to creating the appropriate conditions for research in the language centre environment (Ruane, 2003). It could be done by searching for funding and making collaborative works.

For its unique position and potential role played in the founding institution's development, there have been some efforts to improve the quality of language centre, including its sources and programs, but few research has been carried out. A study conducted by Hradilova (2015) reported an effort to restructure Masyarik University Language Centre by changing its organizational structure. According to Hradilova (2015), the language centre adopted matrix structure in order to enhance quality of co-operation and communication at various levels of the LC both in terms of simplifying its management and exploiting LC pedagogical expertise. Besides, it also promoted teachers' development in teaching and research through training, communication, and internal cooperation.

Therefore, this study was conducted to design an SOP on the LC's program in order to guide the management team to design and implement programs so that the LC could fulfill the characteristics of a language centre based on its programs. The SOP design was also part of the LC's restructuring so that it is able to function as a language centre, not language teaching centre.

\section{METHODOLOGY}

The research employed three phases of ADDIE (Branch, 2009), that are Analyze, Design, and Develop. The Analyze phase aimed to identify the probable causes for a performance gap (Branch, 2009) that commonly result from lack of resources, lack of motivation, and lack of knowledge and skills.
The purpose of the Design phase was to verify the desired performances and appropriate testing methods (Branch, 2009) that will decide how to close the performance gap. The Develop phase intended to generate and validate selected procedure. The data was gathered through qualitative approach by doing document analysis, observation, and interview. It was analyzed through data condensation, data display, and drawing and verification conclusions (Miles, Huberman, \& Saldaña, 2014).

\section{RESULTS AND DISCUSSION Results}

Analyze. A preliminary study was conducted in the LC to analyze its management and programs. The researcher analyzed some documents including the language centre's vision, mission, purpose, objective, program, management, and structure. According to the Decree of Head of College, the language centre was established as an organization under the college whose main activities are in language teaching, cultural introduction and exchange, and community service and research and development in language and culture. Besides, the decree also mentioned that the language centre was to give consultation and guidance on language education to schools and study programs. There were four central language programs, English, Pali, Sanskrit, and Javanese. Its purposes are providing means of language teaching and learning, promoting local culture, and establishing a continuous and harmonious relationship with Buddhist and international society through its programs and activities. They are represented in the language centre's vision as becoming a linguistics institution and development by applying three missions in language teaching, research, and community service.

Furthermore, the document of LC's programs showed that since being established in 2014, it had held several programs in 
language training, Indonesian-English translation and vice versa, community service, and cultural activity. Amongst them, language trainings dominated, with short course, coaching clinic, and regular class in English, Pali, French, Javanese, and Japanese. However, English program was the most frequent one. In spite of short course and coaching clinic, English regular class in undergraduate study program became the main program in the LC. But, it did not have any program in regular class in Pali and Sanskrit, nor in the graduate program. The community service was also dominated by English program.

The preliminary study also found that the LC was the first language institution established by the college. It means that it was the founding institution's first ever experience in managing a language centre. Moreover, amongst fourteen Buddhist colleges in Indonesia, the college was the first one that established a language centre. It, however, was only managed by a director who was also an English lecturer in the founding institution. The director was supported by some students who worked as part-time staff. Usually, the LC hired another teachers outside the institution when holding language programs. Pali, Sanskrit, and another language teacher in the institution did not affiliate with the LC. Moreover, there was no any SOP applied yet in the LC. Since operating in 2014, the LC depended on the director to manage and run the institution.

The further analysis was done to analyze the LC's performance gap and it is presented in the table below:

Table 1. LC's Performance Assessment

\begin{tabular}{|c|c|c|}
\hline Actual Performance & Desired Performance & Cause \\
\hline $\begin{array}{l}\text { Out of } 11 \text { teaching programs, } \\
\text { only } 1 \text { program held for } \\
\text { Graduate Program }\end{array}$ & $\begin{array}{l}\text { Conducting teaching programs } \\
\text { to all study programs }\end{array}$ & $\begin{array}{l}\text { There is no language activities arrangement in the } \\
\text { founding institution }\end{array}$ \\
\hline $\begin{array}{l}\text { Out of all programs until } \\
\text { October } 2018 \text {, only } 1 \text { program } \\
\text { held for Graduate Program }\end{array}$ & $\begin{array}{l}\text { Conducting programs equally to } \\
\text { all study programs }\end{array}$ & $\begin{array}{l}\text { There is no language activities arrangement in the } \\
\text { founding institution }\end{array}$ \\
\hline $\begin{array}{l}\text { Out of all programs until } \\
\text { October } 2018,11 \text { teaching } \\
\text { programs dominated }\end{array}$ & $\begin{array}{l}\text { Conducting teaching, research, } \\
\text { and community service } \\
\text { programs equally }\end{array}$ & $\begin{array}{l}\text { The lack of human resources in language and } \\
\text { operational fund }\end{array}$ \\
\hline $\begin{array}{l}\text { Conducting English Certified } \\
\text { Program as a graduation } \\
\text { requirement }\end{array}$ & $\begin{array}{l}\text { Conducting language program as } \\
\text { part of the academic program of } \\
\text { Undergraduate and Graduate } \\
\text { Program }\end{array}$ & $\begin{array}{l}\text { There is no language activities arrangement in the } \\
\text { founding institution }\end{array}$ \\
\hline $\begin{array}{l}\text { No language research } \\
\text { conducted yet }\end{array}$ & $\begin{array}{l}\text { Conducting language research as } \\
\text { the main activity }\end{array}$ & $\begin{array}{l}\text { The lack of human resources in language and } \\
\text { operational fund }\end{array}$ \\
\hline $\begin{array}{l}\text { No language consultancy } \\
\text { conducted yet }\end{array}$ & $\begin{array}{l}\text { Conducting language } \\
\text { consultancy, especially in the } \\
\text { founding institution }\end{array}$ & $\begin{array}{l}\text { The lack of human resources in language and } \\
\text { operational fund }\end{array}$ \\
\hline
\end{tabular}

Purpose Statement: producing a guide used to guide the LC's management as a language centre

Source: Research Data

Table 1 shows that the LC had mainly operated in language training and teaching. It also played major role in the language program of the Undergraduate Study Program. The LC also did not conduct any research and development program, nor language consultancy program. Its role as a language policy maker only worked in the Undergraduate Study Program.
Therefore, a Purpose Statement was determined, that was producing a guide used to guide the LC's management as a language centre. It was then elaborated into some Instructional Goals that described what to achieve through the SOP design. The Instructional Purposes were identifiying language centre's activities into the LC's programs, designing the programs equally 
based on the qualification of language centre's program, and determining the personnel involved that will conduct the programs.

Based on the data, the Analysis Summary was drawn. First, the LC had focused on language training and teaching, especially English. As Ingram (2001) mentioned, language centre and language teaching centre are two different concepts, as language centre may or may not include language teaching program. It, then, indicated that the LC had shifted to language teaching centre. Besides, as an organization, it was not a synergy and centralization of language resources since there was only one single language resource in English. As Ingram (2001) mentioned, a language centre is characterized through its main programs in applied linguistics, language policy, language consultancy, and research and development. Therefore, the LC needed to have those four main programs and put aside the language teaching and training from their toplist program.

Second, the lack of knowledge and skills in managing a language centre had contributed on the LC's shifting role. The data obtained showed that the LC was the first language institution established by the college and the first language centre in a Buddhist college in Indonesia. This implies that the college was in the learning by doing process, having no referral institution to learn for in managing a language centre in a Buddhist college in Indonesia. Therefore, the LC should have sought some opportunities to have collaborative works with institutions and hire other individuals in realizing its programs.

Third, a plan on designing a Standard Operating Procedure (SOP) on the LCs programs was drafted. It aimed at both closing the performance gap resulting in the LC's shifting role and preparing the next phase, Design. As the LC was the first language institution established by its founding institution and the first language centre in a
Buddhist college, it needed another language institution in a religion-based higher educational institution as comparison. Thus, a benchmarking was planned to be carried out in a language unit (LU) in an Islamic-based higher educational institution, which was located not far from the LC. Furthermore, a SWOT analysis was planned to be conducted to develop the LC's organizational design as a language centre.

\section{Design. Benchmarking in a Language} Unit (LU) in an Islamic-based Higher Educational Institution. The benchmarking was conducted by applying four basic stages of benchmarking (Zairi, 2004 as cited in Goncharuk, Lazareva, \& Alsharf, 2015). They are planning, data collection, analysis, and realization. In the planning stage, the researcher indicated three important sectors to be benchmarked. They included the unit's programs, management, and governance. The researcher also decided to use interview and observation as the data collection method.

In the data collection phase, the researcher interviewed the Head of LU about its programs, governance, and management. The LU was first established in 1999, two years after the State Islamic College (at that time) was established. It serves as a language standardization, Arabic and English for students as there are many learning sources that are in Arabic and English. Besides, it also provides document translation service for the founding institution, students, or society in Arabic and English. The LU was also aimed at providing language test training for lecturers and students, such as TOEFL and IELTS for English and ILAik for Arabic.

Once, it was focused on the language standardization as the college demanded their students to have standard Arabic and English skills by holding Foreign Language Intensive Study. However, as the students' skills did not improve significantly, the language teaching became the full responsibility of each faculty. 
The LU's role shifted into lecturers' and students' language self-development. It, then, provided language test trainings such as TOEFL, IELTS, and ILAiK, calligraphy, and training on applying for foreign scholarships. It also held cooperation with some foreign institutions, such as RELO (Regional English Language Office), the Embassy of the United States of America, to hold language training and workshop. The LU also hold students' activities such as the commemoration of Arabic Day and English Day, English Camp, Arabic Camp, and local culture preservation. Moreover, it focuses on research and development in language and language teaching and publication on language teaching innovation in their website.

The document study found that as a language unit, the LU comprises professional staff in language and non-language. The Head of LU is a language specialist who authorizes the programs and finance. Its position is in line with the dean in a faculty. Two secretaries in Arabic and English are responsible of translating documents, guiding students in language test training, and managing language enrichment program. Another staff are working in the LU's administrative and academic affairs.

As part of government educational institution, the LU's financing depends on the government. Furthermore, as a unit, it is not allowed to generate its own revenue and get income outside the founding institution.

The design of its office represents the role they have in the institution. The observation conducted describes that the office consists of two areas. The first is the office for the Head, secretaries, and staff. There was also a table provided for an English teacher from the RELO since the LU was in collaboration with RELO in English teaching and learning. The second area is a self-access learning centre that consists of two areas representing the institute's language focus: Arabic and English. The Arabic learning room is called Zawiya Arabiya and the English learning room is called English Rendezvous. It is completed with books, computers, and a set of gamelan (traditional Javanese music instruments). The room is usually full of students who want to have a group study or learn Arabic and English independently.

The benchmarking went into further stage, realization. Based on the LU's design as a language unit in an Islamic institute, the researcher decided the LC's design as a language centre in a Buddhist college. The design included its governance, management and programs. It is presented as follows:

Table 2. LC's Design as a Language Centre in a Buddhist College

\begin{tabular}{|c|c|}
\hline Characteristics & Description \\
\hline Scope & A language centre in a Buddhist college \\
\hline Governance & Under the Head of College, an advisory or governing body needed \\
\hline Management & $\begin{array}{l}\text { 1. Director, responsible to Head of College } \\
\text { 2. A governing or advisory body needed } \\
\text { 3. Academic and administrative staff needed }\end{array}$ \\
\hline Finance & $\begin{array}{l}\text { 1. Coming from the founding institution for its operational activities } \\
\text { 2. Must be able to generate revenue }\end{array}$ \\
\hline Focus & $\begin{array}{l}\text { Pali, English, Sanskrit, and Indonesian based on the language learning needs in the college and } \\
\text { another language that can be sold outside of the college }\end{array}$ \\
\hline Activities & $\begin{array}{l}\text { 1. Applied linguistics in language training and document translation } \\
\text { 2. Language policy maker in the founding institution } \\
\text { 3. Language consultancy service } \\
\text { 4. Research and community service in language and culture } \\
\text { 5. Local culture preservation program } \\
\text { 6. Inter-cultural exchange program }\end{array}$ \\
\hline
\end{tabular}


Table 2 shows the LC's design as a language centre in a Buddhist college. The governance and management considered the founding institution's structure so that the founding institution was able to run its controlling function to the LC. The finance condition was based on the characteristic of a language centre that it should be able to generate revenue (Ingram, 2001). The focus was based on the language needs in the founding institution so that it did not include Javanese. And, the activities were decided based on the initial design of the LC.

SWOT Analysis of the LC. After getting the organizational design of LC in a Buddhist college, a SWOT Analysis was conducted to produce the development strategy of the LC by analyzing the LU's strength, weakness, opportunity, and threat. The SWOT Analysis was conducted in a Focus Group Discussion (FGD) attended by the Head and Vice Head of College, one lecturer representative, one student of undergraduate program, and one student of graduate program. The data was analyzed in the matrix table of IFAS (Internal Factors Analysis Summary) and EFAS (External Factors Analysis Summary). Then, the analysis result of the internal and external factors were weighed and rated and the scores were counted so that it resulted the final score of IFAS and EFAS. The IFAS consists of strength and weakness items. The IFAS table is presented as follows:

Table 3. IFAS (Internal Factors Analysis Summary) Matrix Result of Strength and Weakness Factors Analysis

\begin{tabular}{|c|c|c|c|c|}
\hline NUM. & STRENGTH & WEIGHT & RATING & WEIGHT X RATING \\
\hline 1. & The uniqueness of language programs & 0.3 & 3 & 0.9 \\
\hline 2. & Creativity in conducting programs & 0.3 & 3 & 0.9 \\
\hline 3. & $\begin{array}{l}\text { The reputation of the founding institution as } \\
\text { the best private Buddhist college }\end{array}$ & 0.4 & 4 & 1.6 \\
\hline \multicolumn{2}{|r|}{ TOTAL } & 1 & 10 & 3.4 \\
\hline NUM. & WEAKNESS & WEIGHT & RATING & WEIGHT X RATING \\
\hline 1. & \multirow{2}{*}{$\begin{array}{l}\text { Limited sources in language } \\
\text { First experience in managing a language } \\
\text { centre }\end{array}$} & 0.2 & 2 & 0.4 \\
\hline 2. & & 0.1 & 3 & 0.3 \\
\hline 3. & Limited funding & 0.2 & 3 & 0.6 \\
\hline 4. & Limited facility & 0.1 & 2 & 0.2 \\
\hline 5. & Limited language study culture & 0.3 & 1 & 0.3 \\
\hline 6. & Less-strategic location & 0.1 & 4 & 0.4 \\
\hline \multicolumn{2}{|r|}{ TOTAL } & 1 & 15 & 2.2 \\
\hline
\end{tabular}

Source: Research data

The EFAS consists of opportunity and threat items. It is presented as follows:

Table 4. EFAS (External Factors Analysis Summary) Matrix

Result of Threat and Opportunity Factors Analysis

\begin{tabular}{clccc}
\hline NUM. & \multicolumn{1}{c}{ OPPORTUNITY } & WEIGHT & RATING & WEIGHT X RATING \\
\hline 1. & $\begin{array}{l}\text { Cooperation with institutions and individuals } \\
\text { in language programs }\end{array}$ & 0.3 & 4 & 1.2 \\
\hline 2. & $\begin{array}{l}\text { Support from Buddhist and non-Buddhist } \\
\text { donators }\end{array}$ & 0.3 & 3 & 0.9 \\
\hline 3. & $\begin{array}{l}\text { Support from the Department of Religious } \\
\text { Affairs }\end{array}$ & 0.3 & 3 & 0.9 \\
\hline 4. & Support from stakeholder & 0.1 & 2 & 0.2 \\
\hline & TOTAL & 1 & 12 & 3.2
\end{tabular}




\begin{tabular}{clccc}
\hline NUM. & \multicolumn{1}{c}{ THREAT } & WEIGHT & RATING & WEIGHT X RATING \\
\hline 1. & Another more stable language institution & 0.3 & 2 & 0.6 \\
\hline 2. & Decreasing language program interests & 0.3 & 3 & 0.9 \\
\hline 3. & Another more stable language centre & 0.4 & 1 & 0.4 \\
\hline & TOTAL & 1 & 6 & 1.9
\end{tabular}

Source: Research data

After identifying and counting each item of IFAS and EFAS, the final score resulted as follows:

Table 5. Final score of IFAS and EFAS

\begin{tabular}{cccc}
\hline & & & EFAS \\
\hline Category & Total Score & Category & Total Score \\
\hline Strength $(\mathbf{S})$ & 3,4 & Opportunity $(\mathrm{O})$ & 3,2 \\
\hline Weakness $(\mathbf{W})$ & 2,2 & Threat $(\mathrm{T})$ & 1,9 \\
\hline Total $(\mathbf{S}-\mathbf{W})$ & $\mathbf{1 , 2}$ & Total $(\mathbf{O}-\mathbf{T})$ & $\mathbf{1 , 3}$ \\
\hline
\end{tabular}

Source: Research data

Table 5 shows that the LC was in the position of SO (Strength-Opportunity) quadrant. It implies that the LC should use their unique language programs, creativity in designing programs, both in language and culture, and their founding institution's reputation as the best private Buddhist college in Indonesia as their ammunition to be a language centre. Moreover, they should take use of the opportunities available by seeking possible cooperation with institutions and individuals in language programs and having supports from the Buddhist and non-Buddhist donators, Department of Religious Affairs, and stakeholder. It can be done to get the funding they need for their programs.

The Design Brief of the Standard Operating Procedure (SOP) on the LC's programs. The result of the benchmarking and SWOT Analysis gave some notes for the researcher as part of the design of Standard Operating Procedure (SOP) on the LC's programs. First, the LC's programs should comprise language and cultural programs. Second, the programs should represent the three areas of language centre's activity, which are applied linguistics (language research, consultancy, and teaching and training), the improvement of language education, and the implementation of language policy in the institution, nation or region that they serve.
Third, the limited sources the LC should be tackled by developing possible system to recruit another committee or staff outside the LC temporarily or have collaborative works with another unit in the founding institution.

The Design Brief of the Standard Operating Procedure (SOP) on the LC's programs was then composed based on the notes above. First, as the LC's programs are varied, the programs were then divided into three kinds, which were annual, incidental, and thematic programs. Annual programs are those held routinely, being the LC's trademark. Incidental programs are the programs held incidentally, to respond the LC's environment needs. And, thematic programs are those held based on certain themes in language and culture. When designing their programs, the LC can decide the area of the annual, incidental, and thematic programs belong to.

Second, the SOP on the LC's programs consisted of four main parts, which were Introduction, Procedures in the Program Implementation, Additional Provision, and Closing. Those would consist of several parts to accommodate the procedures needed in the SOP.

Develop. As the SOP was aimed at guiding the program implementation in the LC, the title of the SOP was decided to be similar with the kinds of programs. The four main parts 
of the instrument were differed based on each of its function. Section Introduction consisted of five parts, which were General Review, Legal Basis, Objectives, Scope, and Definitions. General Review was the explanation why this SOP was designed. Legal Basis included the decrees and rules that supported the design and implementation of the SOP. Objectives laid out the purposes of the SOP design. Scope mentioned the areas which the SOP dealt with. And, Definitions defined the parties involved in the SOP, including program, director of the LC, staff, committee, and vendor.

Section Procedures in the Program Implementation explained how the annual, incidental, and thematic programs could be implemented. It contained four parts, which were Program Preparation, Program Implementation, Responsibility, and Program Format. Program Preparation included the procedures in preparing the program. Program Implementation described the procedures to implement the program designed. Responsibility comprised each party's jobs when holding a program. And, Program Format illustrated the programs that should be designed and implemented in the LC based on its language focus and activity area.

Section Additional Provision was listed to accommodate the situation where the LC needed to respond special need in its environment. It might have been used or not. Finally, section Closing was kind of statement that the SOP was used as a formal procedure to design and implement the LC's programs.

\section{Discussion}

The SOP designed implies that there was a significant effort to change the LC as an organization. As Cuba (1998) cited by Bush (2007) mentioned that the most basic thing in managing is defending organization's efficiency and effectiveness, making the LC's management team to run the LC's programs based on the characteristic of language centre's programs is the most probable thing to do to address the LC's shifting role. The SOP enables the LC's management team to decide their programs, whether they belong to annual, incidental, or thematic programs based on the three main areas of language centre's activity. This program naming and distinction also encourages the LC's management team for not picking the language teaching and training program as their main program, as language teaching program may or not be included in language centre's program (Ingram, 2001).

Moreover, the program distribution into annual, incidental, and thematic program potentially strengthens the LC's management team to start conducting research and development programs. They can make a research and development program as their annual program by exploring the language teaching practices in the founding institution and making collaborative works with the research institution in the founding institution. Furthermore, the LC's management team can apply for some grants or make collaborative works with another language institution to conduct research and development and put it in the incidental and thematic program. These activities will boost the position of research and development activity in the LC and significantly enhance its status since extensive research practices might contribute to the language centre's work status among departments in university (Ruane, 2003).

The SOP on the LC's program consists of the main elements an SOP should have; they are objective, scope, responsibility, and procedure (Battacharya, 2016). It clearly represents what an SOP needed in an organization since it does not only present the specific procedures, but also defines who does what, the objective of using the procedure, and in what situation it should be used (de Treville, Antonakis, \& Edelson, 2005. It also shows that it can be used as a set of instructions as a standard procedure (Bhattacharya, 2015; Barbé, et. al, 2016; Sadjak, Trembath, \& 
Thomas, 2013; Putranti, 2016), since it contains a set of instructions to conduct the LC's programs step by step.

However, even though the SOP design might enable the LC to make some changes in the LC's structure and resources in the future, it is different with what the language centre's restructuring conducted by Hradilova (2015). Hradilova (2015) focused on the language centre's structure change that was conducted by applying matrix structure to support the equal work distribution and staff's responsibility that improved staff's development. Whereas, the restructuring of the LC concentrated on the program change that was done through applying an SOP in the LC's program.

\section{CONLUSION AND RECOMMENDATION Conclusion}

The SOP designed aimed at providing guide for the LC's management team so that they were able to design and implement the LC programs based on the characteristics of language centre's program. As language centre has a wide range of complex activities to be accomplished, the SOP divided the LC's programs into three kinds of programs; they are annual, incidental, and thematic programs. It was also a part of the LC's restructuring process by changing the LC's activities that, inevitably, would make the LC manage their own resources and change their organizational structure in the future.

\section{Recommendation}

Even though the research has successfully produced an SOP on the LC's program, however, the SOP should be reviewed, authorized, and tested to make sure that it meets the LC's needs to act as a language centre based on its programs.

\section{REFERENCES}

Akyar, I. (2012). Standard Operating Procedures (What they are good for?). In Akyar, I (Ed.), Latest research into quality control (pp. 367-391). Rijeka, Croatia: IntechOpen.

Barbé, B., Verdonck, K., Mukendi, D., Lejon, V., Kalo, J.L., Alirol, E., ... Jacobs, J. (2016). The art of writing and implementing Standard Operating Procedures (SOPs) for laboratories in low-resource settings: Review of guidelines and best practices. PLOS Neglected Tropical Diseases, 10(11), 112. doi: 10.1371/journal.pntd.0005053

Bhattacharya, J. (2015). Guidance for preparing Standard Operating Procedures (Sops). IOSR Journal of Pharmacy, 5(1), 29-36. Retrieved from https://www.academia.edu/11454777/G uidance_for_Preparing_Standard_Oper ating_Procedures_Sops_

Branch, R.M. (2009). The instructional design: ADDIE approach. New York, NY: Springer.

Bush, T. (2007). Educational leadership and management: Theory, policy, and practice. South African Journal of Education, 27(3), 391-406. Retrieved from wrap.warwick.ac.uk/426/

De Treville, S., Antonakis, J., \& Edelson, N.M. (2005). Can Standard Operating Procedure Be Motivating? Reconciling Process Variability Issues and Behavioural Outcomes. Total Quality Management. 16(2), 231-241, from https://www.researchgate.net/publicatio n/271671830_Can_standard_operating _procedures_be_motivating_Reconcili ng_process_variability_issues_and_beh avioural_outcomes1

Ferdous, J. (2016). Organization theories: from classical perspective. International Journal of Business, Economics, and Law, 9(2). Retrieved from http://ijbel.com/wpcontent/uploads/2016/05/K9_11.pdf 
Goncharuk, L.G., Lazareva, N.O., \& Alsharf, L.A.M. (2015). Benchmarking as a performance management method. Polish Journal of Management Studies, 11(2), 27-36. Retrieved from http://yadda.icm.edu.pl/yadda/element/ bwmeta1.element.baztech-2e7994a3f0d3-419a-9cce20b12ce6f041/c/Goncharuk.pdf

Hradilova, A. (2015). Language centre matrix management structures: Developments in teacher training. OpenEdition Journal, (34)1, 90-105. Retrieved from http://journals.openedition.org/apliut/5 037\#tocto1n1

Ingram, D. E. (2001). Language centres: Their role, function, and management. Amsterdam, The Netherlands: Jon Benjamins Publishing Co.

Kinicki, A. \& Williams, B.K. (2013). Management: A practical introduction (6 ${ }^{\text {th }}$ ed.). New York, NY: McGraw Hill Irwin.

Miles, M.B., Huberman., A.M., \& Saldaña, J. (2014). Qualitative data analysis: A methods sourcebook ( $3^{\text {rd }} \quad$ ed.).
California, CA: SAGE Publications, Inc.

Putranti, R.I. (2016). Improvement on document control review system in document control section at PT. ASIKA, Cikarang. Journal of Industrial Engineering, 1(1), 36-42. Retrieved from http://ejournal.president.ac.id/presunivojs/inde x.php/journalofIndustrialEngineerin/art icle/view/28/27

Ruane, M. (2003). Language centres in higher education: Facing the challenge. Asp Open Journal, 1-18. doi: 10.4000/asp. 1127

Sadjak, R., Trembath, L.A., \& Thomas, K.S. (2013). The importance of Standard Operating Procedure in clinical trials. Journal of Nuclear Medicine Technology, 41, 231-233. doi: 10.2967/jnmt.113.121467

Tran, Q. \& Tian, Y. (2013). Organizational structure: Influencing factors and impact on a firm. American Journal of Industrial and Business Management, 3 , 229-236. doi: 